\title{
Changing places: spatial ecology and social interactions of female and male Montagu's Harrier (Circus pygargus) in the Spanish Extremadura
}

\author{
Brigitte Berger-Geiger $^{1}\left[\right.$ [ $\cdot$ Georg Heine ${ }^{2} \cdot$ Ajayrama Kumaraswamy $^{1} \cdot$ C. Giovanni Galizia ${ }^{1}[$
}

Received: 21 September 2020 / Revised: 1 March 2021 / Accepted: 9 July 2021 / Published online: 3 August 2021

(c) The Author(s) 2021

\begin{abstract}
The ground nesting raptor Montagu's Harrier breeds in loose colonies in cereal fields in the Spanish Extremadura. It is unclear how and whether birds in different colonies interact and how harriers spend time before and after nesting, before starting migration. We used GPS-GSM tags deployed on ten females and three males, some over multiple seasons, to follow bird movements with unprecedented detail. Arriving from spring migration, all males and most females returned to their old nest site, and spent between 13 and 25 days in mate choice and local site inspection. During incubation and early nesting female movements were strongly reduced, but increased significantly during late nesting and post-fledging periods. After fledging or after breeding failure, females increased their flying radius. Some of them visited other colonies, for single days or for longer periods, or flew long distances within Spain. These visits might have included help in breeding attempts of other pairs (adoptions). Four out of six females returned to their own breeding site before starting migration. Several females repeatedly used common roosts in this phase. Non-breeding females were active in defending nests in the colony against predators. Females with successful brood initiated migration earlier and spent less time in Spain than non-breeders or those with predated nests. Unlike females, daily distances in males were more uniform. While all males remained in the breeding area for the entire season, their activity centres shifted more within that area than those of females.
\end{abstract}

Keywords Circus pygargus $\cdot$ GPS-tracking $\cdot$ Home ranges $\cdot$ Pre-migratory movements $\cdot$ Social interactions

\section{Zusammenfassung}

Soziale Interaktionen und Raumnutzung bei Wiesenweihen (Circus pygargus) in der spanischen Extremadura Die Wiesenweihe, ein bodenbrütender Greifvogel, nistet in Getreidefeldern in der spanischen Extremadura in lockeren Kolonien. Bisher ist nicht bekannt, ob und in welcher Form Vögel in verschiedenen Kolonien miteinander interagieren und wo sie die Zeit vor und insbesondere nach dem Brutgeschäft verbringen, bevor sie die Migration Richtung Afrika starten. Wir konnten mithilfe von GPS-GSM-Loggern die Flugbewegungen von 10 Weibchen und 3 Männchen-teilweise

Communicated by O. Krüger.

Brigitte Berger-Geiger

Brigitte.Berger-Geiger@gmx.de

Georg Heine

Georg.Heine@uni-konstanz.de

Ajayrama Kumaraswamy

ajayrama.kumaraswamy@uni-konstanz.de

C. Giovanni Galizia

giovanni.galizia@uni-konstanz.de

1 University of Konstanz, Universitätsstr. 10, 78457 Konstanz, Germany

2 Max-Planck Institute for Animal Behavior, Am Obstberg, 78315 Radolfzell, Germany 
über mehrere Brutzyklen hinweg_-in hoher Auflösung verfolgen. Nach dem Frühjahrszug kehrten alle Männchen und die meisten Weibchen wieder an ihre vorjährige Brutstätte zurück und verbrachten 13-25 Tage mit Partnerwahl und der Suche nach einem geeigneten Neststandort. Während des Brutvorgangs und der ersten Hälfte des Nestlingsstadiums waren die Flugbewegungen der Weibchen stark eingeschränkt; sie nahmen signifikant zu in der zweiten Hälfte des Nestlingsstadiums und der Bettelphase der flüggen Jungvögel. Nach dem Flüggewerden der Jungvögel oder nach Nestverlust dehnten die Weibchen ihren Bewegungsradius aus; einige besuchten andere, weiter entfernte Kolonien (90-250 km) entweder nur für einen Tag oder für längere Zeit oder sie unternahmen lange Erkundungsflüge durch Spanien. Die Besuche bei anderen Kolonien dienten möglicherweise auch der Unterstützung beim Brutgeschäft bis hin zu einer Nest-Adoption. Vier von sechs Weibchen kehrten vor Migrationsbeginn wieder an ihre Brutstätte zurück. Einige Weibchen fanden sich in dieser Zeit an einem gemeinsamen Schlafplatz ein. Nichtbrütende Weibchen in der Kolonie setzten sich aktiv für den Schutz der brütenden Weibchen ein, indem sie mögliche Prädatoren mobbten und aus der Kolonie vertrieben. Weibchen mit erfolgreicher Brut starteten die Migration früher und verbrachten weniger Zeit in Spanien als Nichtbrüter oder Weibchen mit Nestverlust. Im Gegensatz zu den Weibchen waren die täglichen Flugdistanzen der Männchen einheitlicher. Alle Männchen blieben die ganze Saison lang im Brutgebiet, allerdings verlagerten sich darin die Aktivitätszentren deutlicher als bei den Weibchen.

\section{Introduction}

When studying bird movement, much emphasis has been placed on studying the relationship between breeding and non-breeding movements, particularly for migratory species, and thus comparing needs during migration and wintering vs breeding areas (Berthold 2001). However, movements within the breeding areas, both within and between breeding seasons, are also important because they reveal the spatial scale at which it is important to manage and protect a species. Within-breeding season movements include, for example, movements between breeding place and foraging areas and give indication of the area needed for food supply (foraging habitats may be different from nesting habitats). Movements after breeding and before migration, so called pre-migratory movements, may be used to investigate places for future years, or to fuel up before migration (Arroyo et al. 2002a; Trierweiler et al. 2007; Limiñana et al. 2008).

Tracking technologies have facilitated understanding movement patterns of individual birds. Both satellite tracking based on the Argos system (http://www.argos-system. org/) and GPS-tracking technology (Global Positioning System) have revolutionised the study of animal movements (Trierweiler et al. 2007; Bridge et al. 2011; Limiñana et al. 2012b; Klaassen et al. 2014; Bouten et al. 2013; Kays et al. 2015). Combining GSM (Global System for Mobile Communication) and GPS in a single device allows transferring accurate position data efficiently. Solar powered tags have the potential to operate and give useful data throughout the remaining bird's life. Thus, it is possible to monitor individual birds for long periods and identify individual decisions both in the breeding area and during migration over several years. The biggest challenges for such devices are reduction of size and power consumption (Fiedler 2009). The new satellite technology ICARUS (International Cooperation for Animal Research Using Space) will increase the resources in telemetry (Wikelski et al. 2007).
The Montagu's Harrier (Circus pygargus) is a mediumsized, semi-colonial migratory raptor that breeds from Western Europe to Asia. As a ground nesting species (mainly in cereal), it is dependent on conservation programs during breeding all over Europe. Main threats are loss of natural habitats, loss of clutches and brood due to harvesting activities in agricultural land, and the use of pesticides which reduce prey populations (Arroyo et al. 2004). About half of the breeding population in Europe is located in the south-western Iberian Peninsula (including Extremadura). Recently, the population of Montagu's Harrier in Extremadura suffered a steep decline from about 1000 breeding pairs in 2006 to about 600 breeding pairs in 2017 (Arroyo et al. 2019). Montagu's Harriers are food generalists, feeding on small mammals, small birds, reptiles and insects; in Extremadura, the proportion of small birds and insects is large (Terraube and Arroyo 2011). Birds from Western Europe fly to the Sahel to overwinter and come back to their breeding sites in April. Little is known about movements of adult harriers for the period when the youngsters have left the nesting area, before migration starts, although it is known that harriers perform dispersing movements at that time, possibly visiting good foraging areas or future breeding sites (Limiñana et al. 2008; Strandberg et al. 2008; Trierweiler 2010). Migration onset of Spanish Montagu's Harriers is between the end of July and the beginning of September (Limiñana et al. 2008).

Juveniles show relatively high natal dispersal (Arroyo 1995; Chadœuf et al. 2017; Bourrioux et al. 2017). Once they have established a brood area, Montagu's Harriers are thought to return to the same site for several years (Clarke 1996). In some cases, breeding dispersal of distances $<100 \mathrm{~km}$ has been observed using wing tag data (Arroyo and Bretagnolle 2000) and satellite data (Trierweiler 2010). Several studies investigated home ranges and found big variation both between individuals, years and different environmental conditions, indicating different space 
use strategies (Klaassen et al. 2019). Females' home ranges were considerably smaller than those of males; though for both sexes large variation is reported. Males/females used home ranges from $11.5 / 6 \mathrm{~km}^{2}$ (95\%) in Schleswig-Holstein (North Germany) (Grajetzky and Nehls 2017), $14 \mathrm{~km}^{2}$ (only males) in France (Salamolard 1997), $35 \mathrm{~km}^{2}$ (90\%, only males) in the Netherlands (Trierweiler 2010), up to $67 / 5 \mathrm{~km}^{2}$ (90\%) in Poland (Krupiński et al. 2021), 90/28 km² (95\%) in North-West Germany (Greiwe 2020) and $104 \mathrm{~km}^{2}(90 \%$, only males) in Catalunya (Spain) (Guixé and Arroyo 2011). This variability indicates that food supply differs in different environments, though a part of the variability is likely due to different methodologies uses (both for tracking and for calculating home ranges), and to differences across individuals.

Here, we study movement ecology of $C$. pygargus in the Spanish Extremadura. We use GPS-GSM methodology to (1) describe and quantify the home range size and spatial parameters during the pre-breeding, breeding (incubation, nesting and dependency period) and post-breeding periods (2) describe and study possible interactions between individuals and colonies, (3) analyse post-breeding and premigratory movements of different individuals, both males and females and (4) report about site fidelity.

\section{Methods}

\section{Study species and study area}

Montagu's Harriers arrive in the breeding areas of Extremadura over a period of several weeks in March or early April, performing pre-breeding movements that may last up to 3 weeks (Arroyo 2004). Onset of egg laying normally occurs between mid-April and mid-May, clutch size is four to five eggs, occasionally up to six eggs (Arroyo et al. 2004; Berger-Geiger et al. 2019). Hatching date was determined in the field for each nest by visual inspection of the chicks' age comparing to a paper photo-gallery that was provided for field work. We estimated ageing precision by independent second visits to the nest, and found a mismatch in the range of 2-3 days, possibly due to differences in feeding. Hatching date of the oldest chick was used for the entire nest.

The breeding area in 'La Serena' covers around $350 \mathrm{~km}^{2}$, and is situated in the southeastern part of Extremadura (south-western Spain) between the towns of Cabeza del Buey, Castuera and Villanueva de la Serena, at an altitude of $400-550 \mathrm{~m}$ above sea level (Fig. 1). It is a flat landscape, occupied by a pseudo-steppe, where land use is mainly a rotating mosaic of cereal, pasture and fallow land, representing the traditional way of farming to allow soil recovery

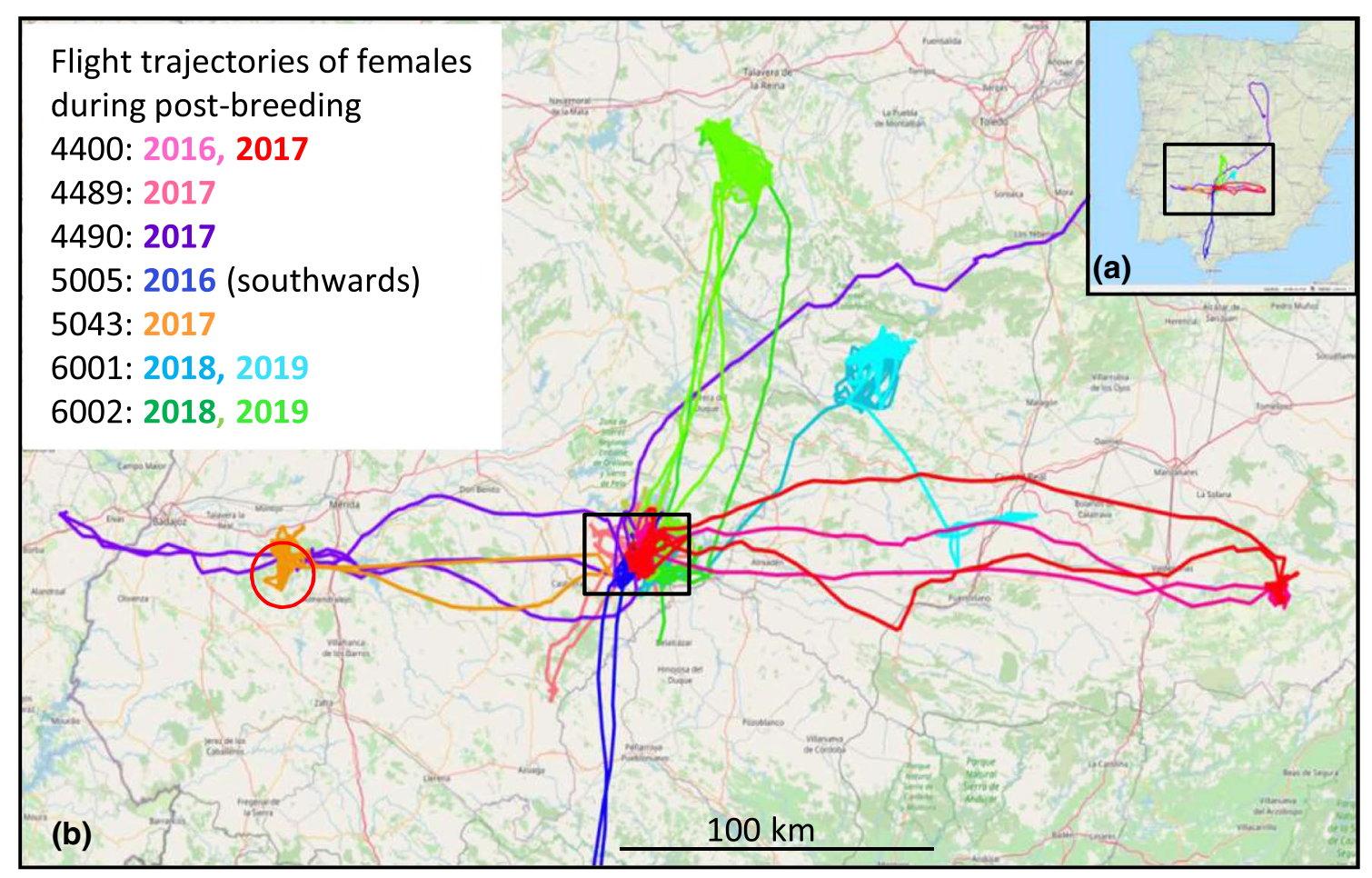

Fig. 1 Location of the study area and exemplary flight traces. a Overview of Spain. Black rectangle indicates close-up in $\mathbf{b}$. b Flight traces of seven females $(4400,4489,4490,5005,5043,6001$, and 6002). Females undertook long exploratory flights to other colonies after breeding. Two females (4490 and 5043) were tagged near Mérida (red circle), the other four at the study site 'La Serena' (centre: black rectangle) 
between crops. Montagu's Harriers find both breeding habitats (mainly in winter sown oat or barley), and hunting areas there. 'La Serena' has 110-130 breeding pairs, most nests are clumped in colonies, with an average distance between nests of $131 \mathrm{~m}$ (Berger-Geiger et al. 2019). About 35\% of the population is found in 1-2 large colonies (each holding $15-45$ breeding pairs), while the size of most other colonies ranges between 4 and 14 pairs (Berger-Geiger et al. 2019). 'La Serena' hosts approx. 15-20\% of the Extremadura population as a whole (pers. communication Manuel Calderón) and 2.5-3.5\% of the Spanish population. Another breeding site in Extremadura is near Mérida (Fig. 1b, red circle) $110 \mathrm{~km}$ west of 'La Serena', where Montagu's Harriers breed in cereal fields between olive plantations and vineyards and form colonies of up to 5 breeding pairs (pers. communication José María Abad).

\section{GPS-GSM tracking}

Between 2016 and 2018, we equipped eight females in 'La Serena' and two females from a colony near Mérida with GPS-GSM-solar powered data-loggers manufactured by the University of Konstanz (Choi et al. 2016). Device (15 g) and harness $(2 \mathrm{~g})$ amounted to a maximum of $5 \%$ of the individual's body mass (Kenward 2001; Caccamise and Robert 1985). In 2019, we tagged three males with $10 \mathrm{~g}$ devices from Ornitela (https://www.ornitela.com/10g-transmitter) within a project of GEA (Grupo Extremeño de Aguiluchos) supported by the Dirección General de Sostenibilidad de la Junta de Extremadura. Birds were trapped using a gaze net with a stuffed raptor (i.e. Bubo bubo) as a decoy, placed close to their nests. To prevent nest abandonment, birds were only trapped if they had nestlings in the nest. The transmitters were mounted in a backpack configuration and attached using Teflon ribbon. Birds were released within $30 \mathrm{~min}$ after capture. Tagged individuals are identified by the ID of the data logger throughout the paper. All three males were trapped at the same site within a colony of nearby nests.

Tags for females were programmed to collect at minimum 1 GPS position per day and 1 during the night, and up to one position every $15 \mathrm{~min}$ under favourable battery conditions. Data were transferred daily by GSM network and uploaded to 'Movebank' (Wikelski and Kays 2010; https:// www.movebank.org). Ornitela loggers transmitted about 30 GPS positions per day. All data are available in the study "LifeTrack Circus pygargus" in Movebank, download permission can be requested from the authors.

\section{Data analysis}

We inspected the GPS data against outliers, and found that some data points had "impossible" values, e.g. altitudes below sea level. We, therefore, excluded GPS reads with any of the following: coverage of less than 4 or more than 18 satellites, height above $6000 \mathrm{~m}$ or below sea level, battery level outside the range 1000-2000 (for the Konstanz tags), or geographical longitude outside the range -20 to 5 . Of 15,677 GPS-fixes for ten females, this led to 20 excluded fixes, corresponding to $0.13 \%$. Of 16,381 GPS-fixes for three males, 3 were excluded $(0.02 \%)$.

We defined the following time periods for analysis: (1) pre-breeding, as the time between arrival (the day the bird stopped the migration north near the breeding site), and start of egg laying, (2) incubation (29 days, Clarke 1996) and early nesting period (16 days), totally 45 days, (3) late nesting period (16 days; total nesting period is 32 days according to Arroyo 1995); and (4) post-fledging dependency period. This period can vary considerably (Amar et al. 2000; Kitowski 2002; Arroyo et al. 2002b). The maximum length for dependency found for males was 45 days (Amar et al. 2000): we took this time span for males. In most cases females leave the area before the fledglings are independent (Arroyo et al. 2002b), therefore, for females that left the breeding site for another pre-migratory destination, we calculated the time span between the end of nesting period and take off; for females that stayed at the breeding site, we calculated a dependency period of 29 days; (5) post-breeding period up to migration onset. The post-breeding period would usually (after a successful breeding event) start after dependency period or in case of breeding failure after nest loss. We defined this period as 'same colony' if the animal remained at the breeding site, or 'other colony' if the animal had moved away. Distances to 'other colony' were calculated using Google Earth. Start of autumn migration was defined as a southward movement of $>100 \mathrm{~km} /$ day without return flight towards north.

Based on females' movement patterns we could identify the nesting site as central point even if the nest was not localised before. We then examined daily flight distances as to belonging to a specific breeding period. In case there was an unexpected increase of daily flight distances away from the nesting site we assumed nest loss. Flight behaviour after nest loss was attributed to post-breeding period. We defined two females as non-breeders, based on their movement patterns (no central point as nesting site). In the tagging year, we could not completely rule out an early nest loss, but we found both of them the next year to be non-breeders (again).

Males had the centre of their movements within a concentration of nests in a big colony precluding us from assigning the individuals to a particular nest. We, therefore, divided the time span between arrival and migration into 5 (fictive) intervals: pre-breeding, incubation and early nesting, late nesting, dependency and 'same colony'. The latter may coincide with the period the fledglings have left the breeding area (Arroyo et al. 2002b). We cannot exclude completely that the tagged males may have been non-breeders. 
Individuals were tagged during the breeding season: in that year, data collection started with nesting or dependency period, the following year with pre-breeding.

\section{Home range size and statistical analysis}

Home range size analysis was done by calculating Utilization Distribution based on Biased Random Bridges (Benhamou and Cournelis 2010), using AdehabitatHR 0.4.18 (Calenge 2006) written in $R$ by Clement Calenge 2019. Programming was done in Python, with rpy2 (rpy2.github.io) for R packages, and bokeh (bokeh.org), pandas-bokeh (https://pypi.org/ project/pandas-bokeh), and seaborn (Waskom et al. 2020) for interactive graphics display. We plotted, for every bird, all trajectories and calculated home ranges (interactive material available at https://neuro.uni.kn/harrier.html). Home ranges of $50 \%$ kernel-density represent nesting and coreareas, $75 \%$ the actively selected areas for hunting or roosting (Martinez-Miranzo et al. 2016) and $90 \%$ is an estimate of total home range (Trierweiler 2010; Guixé and Arroyo 2011). Home ranges were not calculated for flight segments (linear movement between distant sites).

Daily flown distances were calculated as cumulative distances of measured fixes. These are lower bound estimates, since the birds are likely to have flown additional paths between the fixes taken. As a corollary, on days with few fixes, the underestimate might be larger than on days with many fixes. We, therefore, analysed the relationship of number of fixes vs. km flown. We found a strong effect (fewer fixes never yield very long distances, GLM), but poor predictive power (many fixes do not imply long distances). Therefore, we removed all days with few fixes. For males, removing all days with less than 20 fixes led to fixes not contributing a significant amount of variance in the GLM, for females the cutoff was 15 fixes/day. These cutoff values were used for the analysis of daily distances flown (Supplementary Table S1).

Activity radii were calculated in the following way: for each period and animal, we calculated the geometric median (Torricelli point) (Vardi and Zhang 2000). Next, for every fix, we calculated its distance to that centre. We took the median of these distances for each day, to weigh each day equally, and then calculated the median of these daily values. Unlike home ranges, which have a two-dimensional unit, activity radii are a linear measure. The two can be compared (and correlate strongly) when converting the radius into the surface of a corresponding circle. Activity centre shifts for period transitions were calculated as distance between the activity centres of adjacent periods.

Statistical analysis was done in $\mathrm{R}$, using general linear models (GLM from the stats package) with a log link function and quasipoisson error structure where appropriate. Code sources are available upon request.

\section{Results}

Thanks to the GPS-GSM tags, we could follow the movements of 10 females (16 partial or complete seasons), and 3 males (6 partial or complete seasons) in detail (Table 1, Supplementary Table S1). During breeding, all individuals were found living in (large) colonies. After breeding, several females moved to other areas in Spain, or performed longer flight stretches before starting migration (Fig. 1a, b). All males ( 6 seasons) remained in the breeding area throughout the season (Fig. 2a, b), and started migration from there. Details about females' behaviour and movements are found in the electronic supplementand at https://neuro.uni.kn/harri er.

The Konstanz tags (female animals) reported between 0 and 89 fixes per day (mean 14.0, median $8, n=10$ birds), the Ornitela tags (male animals) reported between 5 and 31 fixes per day (mean 27.8, median 29, $n=3$ birds).

\section{Analysis across periods}

First, we analysed how space was being used by our tagged animals during different periods. We defined four periods for pre-breeding and breeding: (1) pre-breeding, (2) incubation and early nesting, (3) late nesting, and (4) dependency (see "Methods" for how these periods were defined, in particular for males). For post-breeding, we used either 'same colony' when females remained in their colony, or 'other colony' when they flew to a different colony. For these periods, we evaluated cumulative daily distances (Fig. 3a), home range estimates (Fig. 3b), and activity radii (Fig. 3c) as well as activity centres (Fig. 4).

We analysed the daily distances flown as the cumulative distance between all fixes in 1 day (Fig. 3a). This statistic is a lower estimate, since additional flight segments might have occurred between two recorded fixes. Furthermore, with fewer fixes, the underestimating error increases: we only used days with a minimum of 15 or 20 fixes for females or males, respectively (see "Methods"). We found that, overall, males covered $63.9 \pm 29.3 \mathrm{~km}$ every day. Flight distances varied slightly between periods (pre-breeding: $58.1 \pm 24.4$, incubation and early nesting: $70.5 \pm 24.3$, late nesting: $52.3 \pm 17.4$, dependency: $68.2 \pm 33.2$, 'same colony': $49.6 \pm 25.3$, all in $\mathrm{km} /$ day, mean $\pm \mathrm{SD})$. A generalised linear model (GLM, quasipoisson error, log link function) indicated that these differences were significant, and that males flew significantly longer distances during incubation and early nesting $(p=0.008)$. During dependency, males flew longer distances too $(p=0.02)$.

Females flew $27.2 \pm 24.6 \mathrm{~km} /$ day on average. Flight distances varied considerably between periods (pre-breeding: $18.1 \pm 16.2 n=36$ days, late nesting: $5.0 \pm 2.7 n=53$, 
Table 1 Breeding success, days spent in Spain, pre-migratory flights and migration start for tagged individuals in different years, order by year

\begin{tabular}{|c|c|c|c|c|c|c|c|}
\hline & Sex & Breeding success & $\begin{array}{l}\text { Days spent in } \\
\text { Spain }\end{array}$ & $\begin{array}{l}\text { Pre-migratory } \\
\text { flights }\end{array}$ & $\begin{array}{l}\text { Migration start from } \\
\text { breeding site }\end{array}$ & Migration start & $\begin{array}{l}\text { Date of first } \\
\text { fix in Africa }\end{array}$ \\
\hline $4400-16$ & $\mathrm{~F}$ & Yes & & Yes & Yes & 07.08.2016 & 13.08.2016 \\
\hline $5005-16$ & $\mathrm{~F}$ & No & & Yes & Yes & 18.08 .2016 & 18.08 .2016 \\
\hline $4400-17$ & $\mathrm{~F}$ & Yes & 116 & Yes & Yes & 25.07.2017 & 27.07.2017 \\
\hline $4489-17$ & $\mathrm{~F}$ & Yes & & No & Yes & 29.07.2017 & 31.07 .2017 \\
\hline $4490-17$ & $\mathrm{~F}$ & Unknown & & Yes & No & 08.08.2017 & 17.08 .2017 \\
\hline $5043-17$ & $\mathrm{~F}$ & No & & Yes & Yes & 10.08 .2017 & 15.08 .2017 \\
\hline $4488-17$ & $\mathrm{~F}$ & Non-breeder & & No & Yes & 17.08.2017 & 21.08.2017 \\
\hline $4489-18$ & $\mathrm{~F}$ & Yes & 118 & No & Yes & 29.08 .2018 & 30.08 .2018 \\
\hline $6001-18$ & $\mathrm{~F}$ & Yes & & Yes & No & 29.08 .2018 & 30.08 .2017 \\
\hline $6002-18$ & $\mathrm{~F}$ & Yes & & Yes & Yes & 29.08 .2018 & 30.08 .2017 \\
\hline $6003-18$ & F & Non-breeder & & No & Yes & 16.08 .2018 & 01.09 .2018 \\
\hline $6001-19$ & $\mathrm{~F}$ & No & 130 & Yes & No & 08.08.2019 & 09.08 .2019 \\
\hline $6002-19$ & $\mathrm{~F}$ & No & 132 & Yes & Yes & 21.08 .2019 & 23.08.2019 \\
\hline 191516_19 & M & Unknown & & No & Yes & 09.08.2019 & 10.08 .2019 \\
\hline 191643_19 & M & Unknown & & No & Yes & 29.07.2019 & 30.07 .2019 \\
\hline 191644_10 & M & Unknown & & No & Yes & 08.08.2019 & 09.08.2019 \\
\hline 191516_20 & M & Unknown & 138 & No & Yes & 27.08 .2020 & 28.08 .2020 \\
\hline 191643_20 & M & Unknown & 133 & No & Yes & 09.08.2020 & 10.08 .2020 \\
\hline 191644_20 & M & Unknown & 141 & No & Yes & 16.08 .2020 & 17.08 .2020 \\
\hline
\end{tabular}

dependency: $26.6 \pm 21.5 n=143$, 'same colony': $35.1 \pm 25.8$ $n=72$, 'other colony': $46.6 \pm 26.7 n=61$, all in $\mathrm{km} / \mathrm{day}$, mean $\pm \mathrm{SD})$. We excluded incubation and early nesting, because only two birds gave sufficient data for this period ( $n=7$ days; $4.7 \mathrm{~km} /$ day average for these 6 days), since these two birds had excursions to water reservoirs $0.7-1 \mathrm{~km}$ away from the nest. All other females stayed at the nest for this period, and movements decreased to a minimum. Females left the nest for food passes from males only for very short flights (visual observations in the field, and Clarke 1996), too short to recharge the batteries. A generalised linear model (GLM, quasipoisson error, log link function, cumulative distance $\sim$ period + bird) indicated distances flown differed significantly across periods analysed ( $p=0.001$ for dependency, $p<0.001$ for all other groups). When selectively testing 'same colony' against 'other colony' there was no significant difference between these two groups, though the significance was close to $5 \%(p=0.056$, GLM, quasipoisson error, log link function).

Next, we analysed home range areas for males and females and all periods (Fig. 3b). The procedure used considered that recorded fixes were not equidistant in time (biased random bridge, Calenge 2019). The $75 \%$ home range indicates the estimated area that a bird has resided in for $75 \%$ of the time, that is the area that is most heavily used by that bird during that period. Over the entire season, females covered $75 \%$ home ranges of $40 \mathrm{~km}^{2}$ (mean across period). During pre-breeding, females covered smaller home ranges $\left(26 \mathrm{~km}^{2}\right)$. When nesting started, females remained close to the nest with no insolation, with the effect that the tag batteries lost energy and could not send fixes any more (Supplementary Fig. 1). The few remaining fixes were not sufficient to calculate useful home ranges, and therefore, the period incubation and early nesting was excluded for female home range analysis: we estimate an area of close to $0 \mathrm{~km}^{2}$. Home ranges increased gradually during late nesting $\left(0.8 \mathrm{~km}^{2}\right)$ and dependency $\left(29 \mathrm{~km}^{2}\right)$. Males covered home ranges of $74 \mathrm{~km}^{2}$ for the entire season (mean across periods), ranging from a minimum of $45 \mathrm{~km}^{2}$ (late nesting period) to a maximum of $91 \mathrm{~km}^{2}$ (dependency period) for the $75 \%$ home range value (Fig. 3b). Home range values were significantly different across periods both for males and for females (GLM, quasipoisson error, log link function). After dependency, some females stayed in the area ('same colony'), other females flew into another colony ('other colony'), 90-270 km away (Fig. 1a, b): home range areas increased to mean values of $50 \mathrm{~km}^{2}$ for 'same colony', and $120 \mathrm{~km}^{2}$ for 'other colony'.

As a more conservative way to estimate action ranges, we identified the geometric median of all fixes within each period, and calculated the median distance from this activity centre (see "Methods"). Across all periods, females had a radius of $2.1 \mathrm{~km}$, while males had a radius of $3.5 \mathrm{~km}$. Radii differed significantly across periods (Fig. 3c). In females, the average radii were: $407 \mathrm{~m}$ (pre-breeding), $14 \mathrm{~m}$ (incubation and early nesting), $76 \mathrm{~m}$ (late nesting), $872 \mathrm{~m}$ (dependency), $4.4 \mathrm{~km}$ ('same colony') and $4.9 \mathrm{~km}$ ('other colony'). In 
Fig. 2 a Flight trajectory for three males (red, blue, green) for two consecutive years (bright/dark colour) until migration start. Each male used a different space to hunt. b Home ranges for the same individuals (75\%). Home ranges overlapped in a central area. Darker colours refer to 2020, light colours to 2019: note that each male covered approximately the same area in those consecutive years. Male identities: red: 191516; blue: 191643, green: 191644 . See also interactive version at https://neuro.uni.kn/harrier
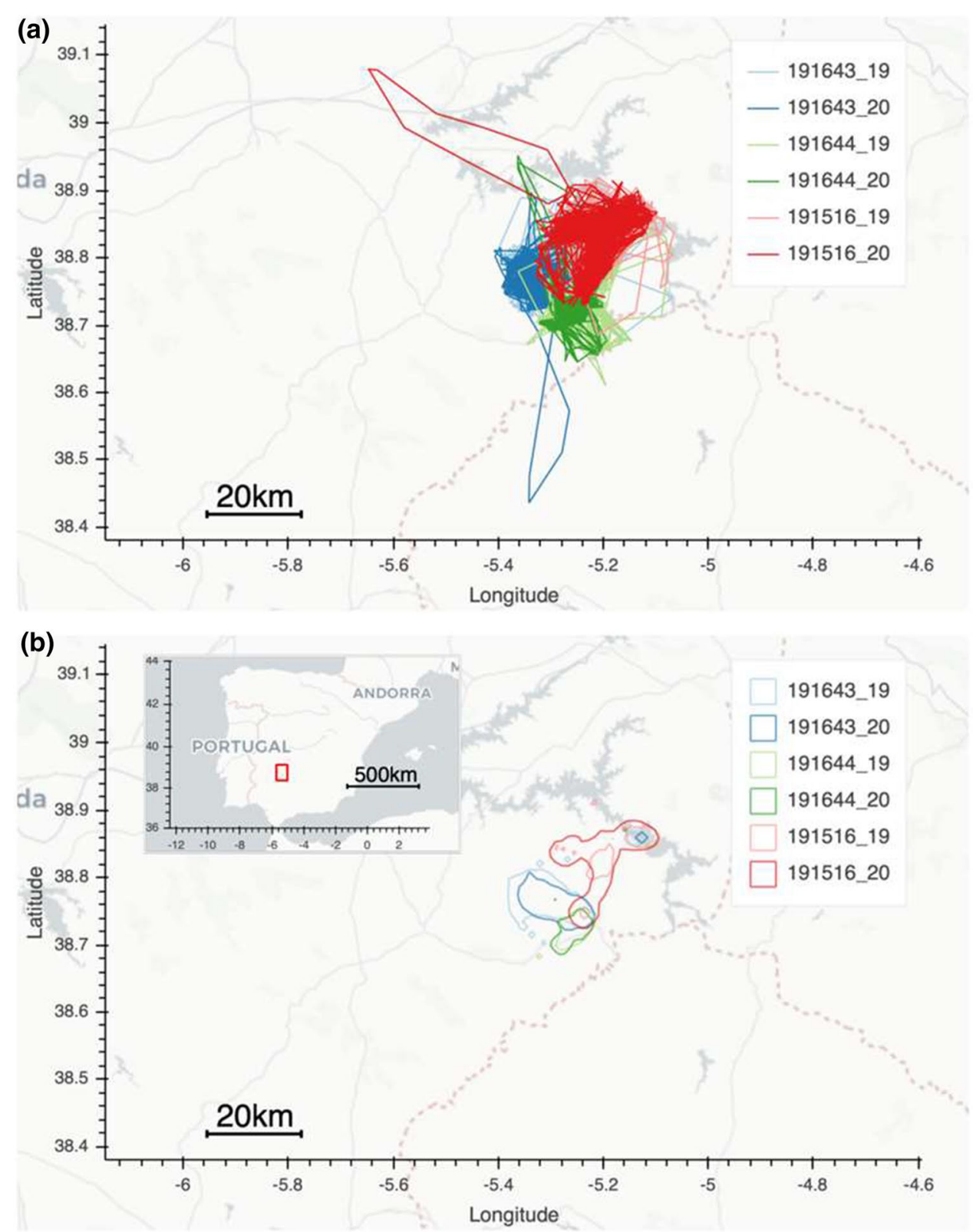

males, the average radii were: $556 \mathrm{~m}$ (pre-breeding), $1.4 \mathrm{~km}$ (incubation and early nesting), $1.3 \mathrm{~km}$ (late nesting), $4.9 \mathrm{~km}$ (dependency), and $5.5 \mathrm{~km}$ ('same colony'). Differences were significant across periods and across sex (GLM).

The strong differences between territory use during breeding by males and by females indicate that their role in providing shelter and food differs. We wondered whether this is apparent also in their localization. Therefore, we analysed their activity centres over the course of the periods. We found that the activity of females is centred on the nest for the entire breeding season (see example in Fig. 4a), while males move over different places in the colony's vicinity (see example in Fig. 4b). Accordingly, the displacement of the activity centre in females is very small during breeding (e.g. $17 \mathrm{~m}$ when changing from incubation and early nesting to late nesting, and $837 \mathrm{~m}$ when changing from late nesting to dependency), while males shifted in space by $7.6 \mathrm{~km}$ and $2.4 \mathrm{~km}$ for these transitions, respectively (median values, $n=3-5$, Fig. 4c). After breeding, activity centres in females shifted significantly to $6.1 \mathrm{~km}$ ( $p=0.014$, GLM). Centre transitions in males did not differ significantly in 


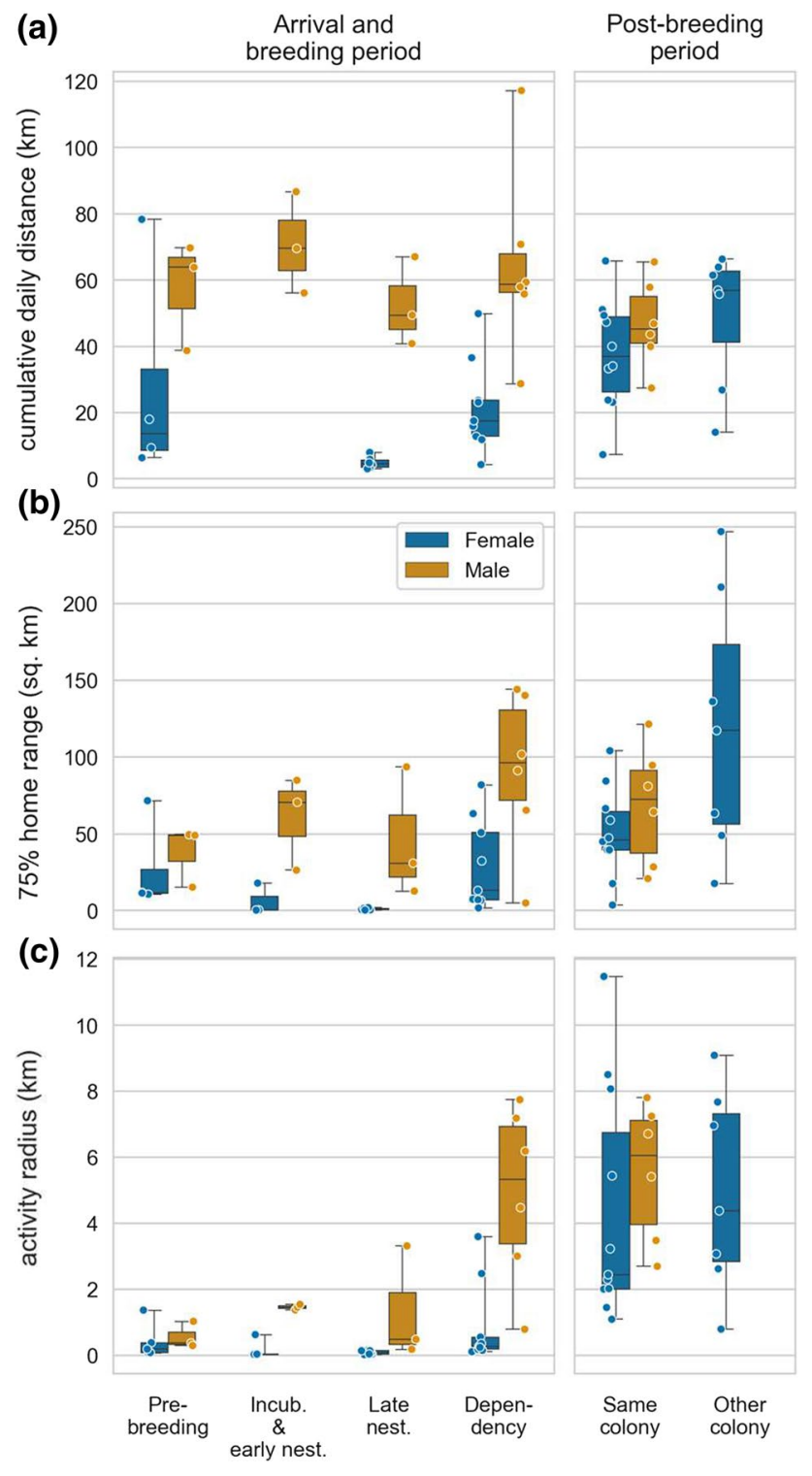

Fig. 3 Space use of males and females across the different periods of the year. Males have a more uniform use of space across the periods, while females are almost stationary during incubation and nesting. See results for statistical analysis. a Daily distance covered by females (blue) and males (brown) during pre-breeding and breeding (left). Post-breeding period (right) for females is split into 'same colony' and 'other colony' (details in the main text), all males stayed within the same colony. Incubation and early nesting has been omitted for females, since females did not move. b Home ranges $(75 \%)$ covered by females (blue) and males (brown) during pre-breeding and breeding (left), and post-breeding (right). c Activity radius for each of the periods. Box plots indicate median and $25 \%$ quantiles, whiskers indicate the full range. Dots with white circles represent individual values magnitude over periods (GLM): their movement over time was continuous.

\section{Interactions between individuals and colonies}

\section{Common roost}

Our loggers reported also positions during night time, allowing us to report about communal roosting (Wiacek 2010), which we define here as nights when fixes were less than $200 \mathrm{~m}$ apart. Over the entire year 2020, males had 40 "common roost" nights. In particular, the pair 191643-191644 spent $27 \%$ of the observed nights in the same roost (but used different hunting areas, Fig. 2), while the other two pairs had $12 \%$ and $2 \%$ common roost nights (see Supplementary Table S2). Females were found in separate places at nights during breeding, indicating the separation of their nests, but night fixes were low due to weak batteries in this period. However, during the post-breeding period, different pairs of females (2-3) from different colonies, including non-breeders as well as one female from the remote colony in Mérida used the same location to roost within $100 \mathrm{~m}$, sometimes closer than $10 \mathrm{~m}$. Across bird pairs, values ranged from no common nights, to $7.5 \%$ common nights (see Supplementary Table S2). We could not analyse roosts common to male and female birds, since in the overlapping year (2019) tagged females were found further away in the post-breeding period ('other colony'), whereas males stayed at the breeding sites ('same colony').

\section{Flights to other colonies}

After dependency, or after nest loss, most females (6 out of 8 breeding females) took off for pre-migratory flights to remote sites (90-270 km away, Fig. 1a, b). They stayed there for periods ranging from single nights to 80 days. Site visits revealed that these areas were occupied by other Harrier colonies and that land use (winter sown cereal, interspersed with pasture and fallow land) was similar to that in 'La Serena' (B. Arroyo, M. Calderón, personal visits).

In 2016, female 5005 from a big colony (> 20 breeding pairs) lost her nest with already big chicks. Thereafter, she visited another big colony ( $>10$ breeding pairs) during 8 consecutive days, about $10 \mathrm{~km}$ away (Fig. 5), daily distances amounted to $21.4 \mathrm{~km}$ on average. During the next 2 weeks her movements were concentrated about a central point $2 \mathrm{~km}$ north-west from the original breeding place; average daily 


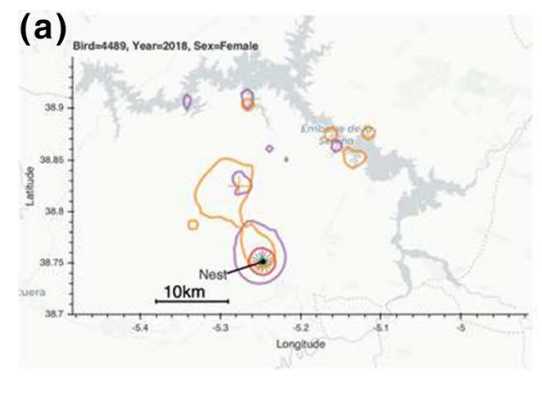

(b)

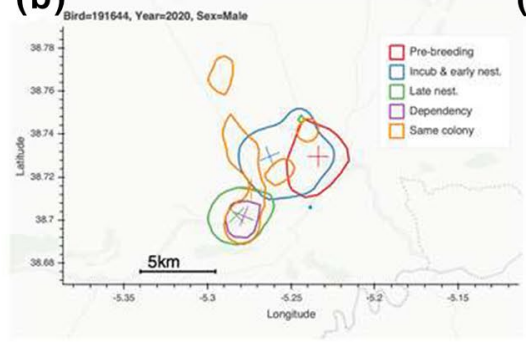

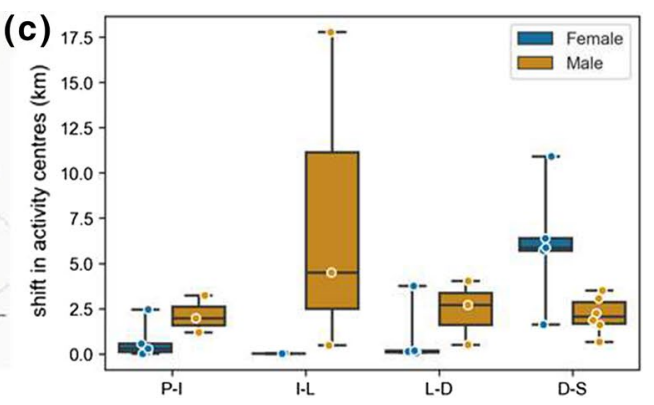

Fig. 4 Shifts across the breeding area in males and females. a $75 \%$ home range area for female 4489 (lines) and position of activity centres (crosses with shifting rotations). The centroids for the periods pre-breeding (abbreviation for $\mathbf{c}$ : $\mathrm{P}$ ), incubation and early nesting (I), late nesting (L), dependency (D) all corresponded to the nest itself. After breeding, the activity centre moved away. b $75 \%$ home range area for male 191644 (lines) and position of activity centres (rotated crosses). The centroids moved to various places, even with strongly overlapping home ranges. Legend in $\mathbf{b}$ applies to both $\mathbf{a}$ and
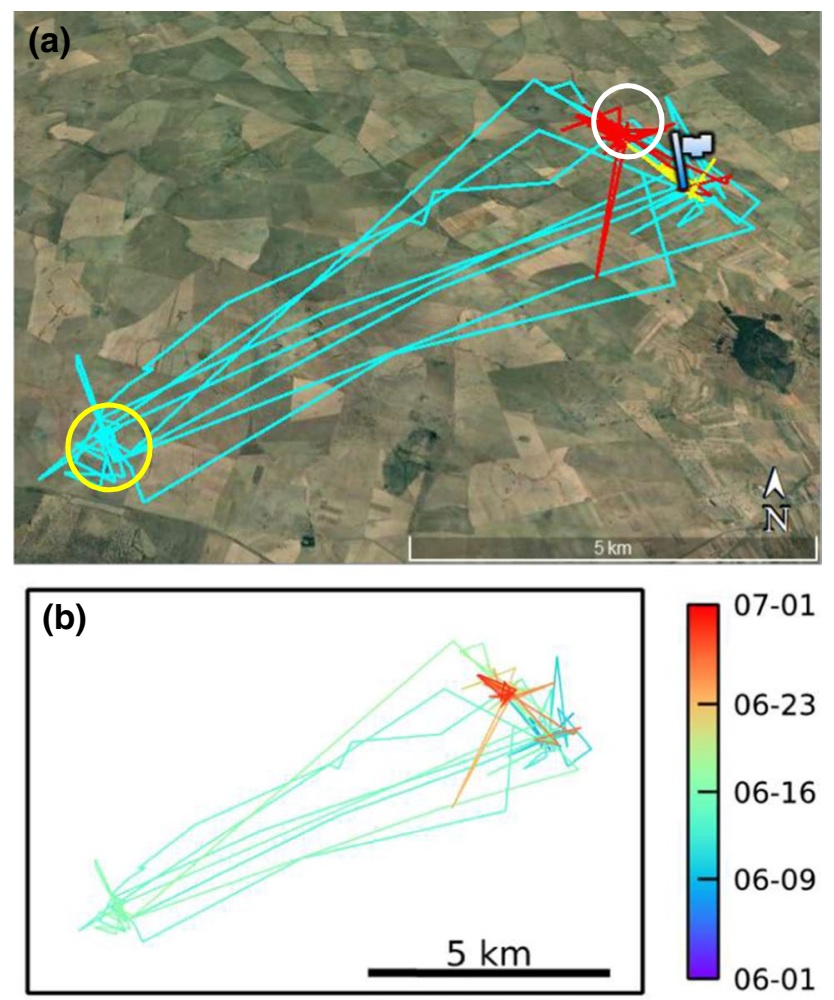

Fig. 5 Movements and putative nest adoption during breeding period for female 5005. a During late nesting (yellow tracts), she stayed close to her nest (flag), until June 10th, when her nest was predated. For 8 consecutive days, she visited another site every day (cyan traces). Then, she moved to another colony (red traces, June 19th to July 1st), where she might have adopted another nest. b Same flight tracts, colour coded for date

distances decreased to $6.0 \mathrm{~km}-$ similar to the distances typically covered during late nesting period. During the following 29 days (putative dependency period), her daily b. c Displacement distances of activity centres from one period to the next (indicated by the letter pair). Females hardly moved between pre-incubation and nesting (left box-plot, P-I), stayed stationary during nesting (transition from early to late nesting, second plot I-L), moved little before dependency (third plot, L-D), and moved more after dependency (here, only birds that stayed within the area are considered, D-S). Males (brown boxes) moved their activity centres throughout the season. See also interactive version at https://neuro. uni.kn/harrier

distances averaged $21.5 \mathrm{~km}$, corresponding to daily distances that females flew during dependency period. We, therefore, hypothesise that she acted as a foster parent for another nest in a nearby colony.

\section{Post-breeding period and pre-migratory movements}

Post-breeding behaviour was diverse: all males (three individuals, six seasons) and three females (one successful breeder, two non-breeders, five seasons) stayed exclusively around the breeding site with only occasional daily flight excursions to sites up to $50 \mathrm{~km}$ away. Two females (two seasons) left the breeding site for only a short visit to a destination farther away: Female 5043 from Mérida (Fig. 1b, orange trace) visited the colonies of 'La Serena' $(110 \mathrm{~km}$ East), stayed for one night and returned to her breeding site. Female 5005 (Fig. 1a, blue trace) took off south to Andalusia $(270 \mathrm{~km})$ on 9th August 2016 but returned north to her breeding site before starting migration (see also interactive plots at https://neuro.uni.kn/harrier).

Three females (successful and failed breeders, six seasons) flew to areas $90-200 \mathrm{~km}$ away from their breeding site (Fig. 1b). In two consecutive years, they took the same route and spent up to 80 days there. Successful breeders took off from their breeding site 21-24 days after fledging of the chicks and stayed 4-20 days at the remote place that was occupied by other colonies of Montagu's Harrier.

We found only one female (4490-17, tagged in Mérida) that explored different sites during her pre-migratory flights (purple in Fig. 1a). During 12 days, she visited twice the colonies of 'La Serena' but went on, flying more than $1500 \mathrm{~km}$ until she stopped at high altitude (1100 m MSL) in an elevated plateau northeast of Madrid in the Sierra de 


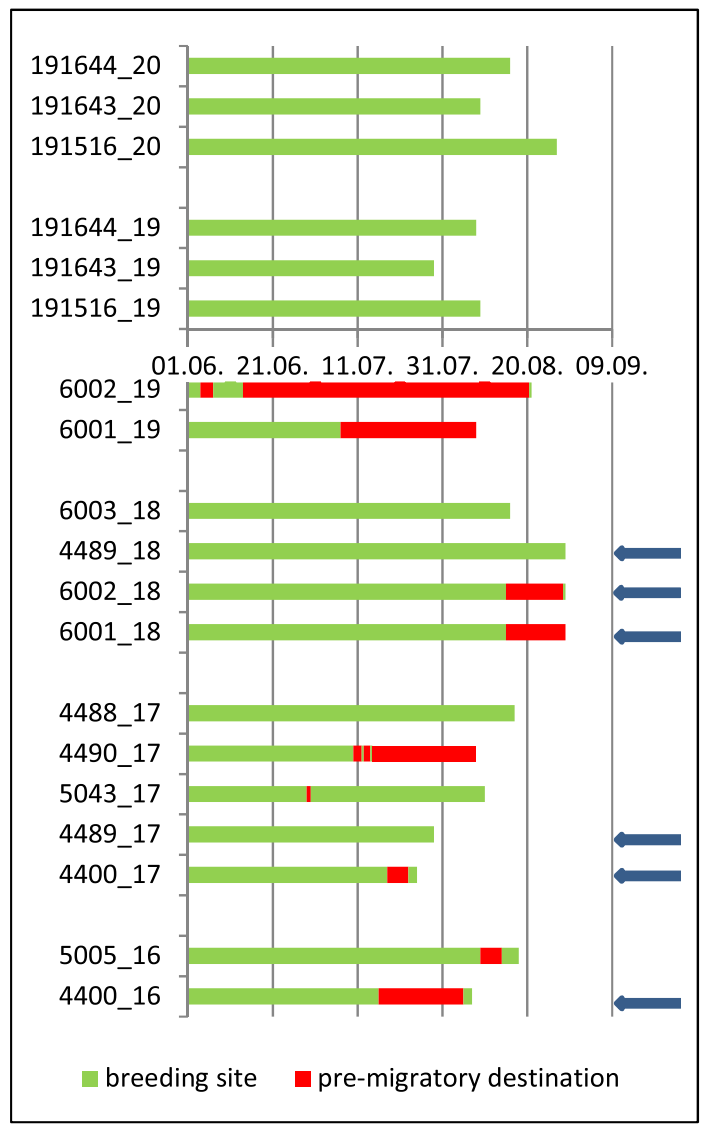

Fig. 6 Post-breeding and migration start. Each horizontal bar represents one animal/year, abscissa gives time, starting with 1st June. Green colour indicates stay at the breeding site, red colour locations far away $(>90 \mathrm{~km})$. Order by year, starting with 2016 . Animals above the abscissa represent three males in 2019 and 2020. End of each bar indicates individual migration start. Females that had successfully raised chicks are indicated by a blue arrow at the right side of the graph

Guadalajara where she spent 17 days (daily distances there: $16.5 \mathrm{~km}$, home range $75 \% 17 \mathrm{~km}^{2}$ ) before starting migration from there. See also interactive material at https://neuro.uni. $\mathrm{kn} / \mathrm{h}$ arrier. The total distance flown during her post-breeding period amounted to $1860 \mathrm{~km}$.

\section{Start of migration}

All three males and three females $(4488,4489,6003)$ started migration from the breeding site without any pre-migratory flights to distant sites (Fig. 6). Most females (4 out of 6) that had visited remote destinations during the pre-migratory period returned to their breeding site and started migration from there (Fig. 6). Only two females $(4490,6001)$ started migration directly from their pre-migratory location without returning to the breeding site.

In 2017, females that were successful initiated migration 11-16 days earlier than failed females and even 23 days earlier than the non-breeder 4488 , the difference was significant (Table 1; two-tailed $t=4.096 ; \mathrm{d} f=3 ; p=0.026$ ). Number of days from arrival at the breeding site until migration start was 116 and 118 days for successful females compared to 130 and 132 days for failed breeders (Table 1) and 133, 138 and 141 days for males. In 2018, breeding season was delayed for about 3-4 weeks, migration was also late and concentrated at the end of August.

\section{Site fidelity}

All three males in our study returned to the same breeding area, using the same hunting sites as the previous year, with strongly overlapping home ranges (Fig. 2). We could not assign the individuals to a particular nest based on their movement patterns; therefore, we do not know whether they were (successful) breeders or not.

Of the five nesting females that we recorded across seasons (four successful, one failed breeder), four selected a nest site close to the previous year's site (distance up to $3 \mathrm{~km}$ ). The fifth (tag 6001), after spring migration, moved east to a site $90 \mathrm{~km}$ away (Supplementary Table S3). There was no relationship between previous year's breeding success and current year's nest location: female 5005 nested just $190 \mathrm{~m}$ away from the previous year's predated nest, while female 6001 moved $90 \mathrm{~km}$ away from the previous year's successful nest.

All tagged females that we could track over two seasons used the same site for their post-breeding/pre-migratory stay. Females 4489 (successful in both years) and 5005 (failed in both years) stayed at their breeding grounds of the previous year during their post-breeding period. Female 6001 had two different breeding sites over consecutive years, but showed site fidelity to her pre-migratory location. Females 4400 and 6002 were faithful both to their breeding and pre-migratory sites in both consecutive years.

\section{Discussion}

Our study analysed movements of GPS-GSM tagged Montagu's Harriers in Extremadura/Spain during pre-breeding, breeding and post-breeding pre-migratory periods. The data show social interactions between individuals and both nearby and remote colonies. We tracked both females and males, revealing important differences between the sexes.

\section{Quality of tagging data}

We used two different types of tags: females were monitored by tags produced in the workshop of the University of Konstanz, while males were monitored by commercial tags (Ornitela), which have less weight and could, therefore, be 
used on the smaller sex. Ornitela tags were more reliable, sending a continuous stream of close to 30 fixes every day. Female tags, however, were less reliable, and several days are missing. This deficit is partly compensated by our using more tags, and monitoring ten females over 16 seasons. Most importantly, when females were nesting and incubating their eggs, covered by crop, their solar cells were shaded, and the tags stopped sending fixes (Supplementary Fig. 1). We can assume that females' movements decreased to a minimum during these periods, since in two females we saw small excursions, and immediately the battery power going up. We do not know whether the Ornitela tag batteries would have been sufficient to cover the nesting period, had they been fixed on females.

\section{Home range usage by males and females}

We found that home range usage in Montagu's Harrier changed considerably for females: after a pre-breeding activity radius of above $400 \mathrm{~m}$, radii dropped to $14 \mathrm{~m}$ during incubation and early nesting, showing that females sit with the eggs and the chicks effectively without flying out, which means they are relying entirely on being fed by males. Radii increased over the season, arriving at close to $5 \mathrm{~km}$ before migration (not counting longrange flights). We calculated three statistics: cumulative distance flown every day (Fig. 3a), home ranges (Fig. 3b, compare with https://neuro.uni.kn/harrier), and activity radii (Fig. 3c), with identical results. Interestingly, males had a totally different pattern: while radii were similar in pre-breeding, during incubation and early nesting and late nesting they increased to $1.4 \mathrm{~km}$ and $1.3 \mathrm{~km}$, respectively, most likely as a result of their activity in providing food not just for themselves, but also for the female in the nest and the chicks. After breeding, males used only slightly larger areas than females $(5.5 \mathrm{~km}$ radius in males vs. 4.4 or $4.9 \mathrm{~km}$ in females). Again, daily distances flown and home ranges gave the same result: increased activity in males during incubation and early nesting, paralleled by no movement in females during that period.

This difference in space usage was also apparent in the centre of activity: females remained centred on the nest for the entire breeding season, while males meandered in the vicinity (Fig. 4). Thus, despite of recent reports that males also participate in direct care to the chicks (Berger-Geiger and Galizia 2019), their contribution is dominated by food provision, and not by presence at the nest.

\section{Female behaviour}

During pre-breeding, four females were centred around their later nesting site (for example female 4489 in Supplementary
Fig. 2a), while one female visited three different sites before settling for one nesting place (female 4400 in Supplementary Fig. 2b). Her inspections might have been related to mate selection, or to site selection. Mate change during the pre-laying period as well as extra-pair copulations in large colonies are reported by Arroyo et al. (2004). We favour the mate selection hypothesis, since this female spent long periods in the first two places, and then abruptly changed to her final choice, a behaviour that does not suggest that she spent time to inspect the locality.

We found no relation between nest site selection and breeding success/failure in the previous year, in contrast to observations in other studies. Arroyo et al. (2004) reported that after failure, females may disperse more than $100 \mathrm{~km}$. As we found one female the next year breeding $90 \mathrm{~km}$ apart from the previous year's successful breeding site we suggest that dispersal might be an individual characteristic, independent from breeding success.

Females' contribution to feeding the chicks during late nesting and dependency period is reported to be variable (Arroyo et al. 2004). Our data show that during this period they fly longer distances than before, but do not allow to estimate their share in feeding the young. However, females that left the breeding site for another destination 21-24 days after fledging evidenced that males could care for the young without females (Arroyo et al. 2002b).

\section{Male behaviour}

During breeding males have to provision the incubating female, and during the first weeks after hatching provision both, chicks and female (Clarke 1996). Males also care for the young during dependency (see above, and Arroyo et al. 2002b). Consistent with this behaviour, we found that males fly long distances throughout the season. Their daily flight distances of $64.0 \pm 29.3 \mathrm{~km} /$ day (all breeding seasons) in this study were approx. 30\% compared to that of males in the Netherlands $(211 \mathrm{~km} /$ day; Schlaich et al. 2017). This may be due to our underestimate of flight distance (see "Methods"). Alternatively, food availability in Spain may be better than in the Netherlands. More research is needed to investigate this point. In our study, home ranges varied considerably between individuals $\left(46-178 \mathrm{~km}^{2}\right.$, mean: $74 \mathrm{~km}^{2}, 75 \%$ over full season), in accordance with the individual behavioural variation and different space use found in other studies (Klaassen et al. 2019). Overall, home ranges were rather large, similar or even more extensive to those found in Catalunya, Spain (104 km² $90 \%$ kernel, Guixé and Arroyo 2011) or in East Poland $\left(67.3 \mathrm{~km}^{2} 90 \%\right.$ kernel, Krupiński et al. 2021). In contrast, very small home ranges have been reported by Grajetzky and Nehls (2017) for Montagu's Harrier in Schleswig-Holstein, Germany $\left(11.5 \mathrm{~km}^{2}\right.$ 
for males and $6 \mathrm{~km}^{2}$ for females, 95\% kernel) and by Salamolard (1997) in France (14 km² for males). Trierweiler et al. (2010) found home ranges of $35 \mathrm{~km}^{2}$ (90\% kernel) for males in the Netherlands. One would expect that within an intensively used agricultural landscape like Germany and the Netherlands Montagu's Harrier need larger home ranges to meet their foraging needs, whereas in areas with traditional small parcels interspersed with natural structures and higher crop diversity (Poland, Spain) prey availability should be much more diverse, and therefore, small home ranges should be sufficient to supply enough food for the harriers and their brood. Apparently, in Schleswig-Holstein, Montagu's Harrier found high-quality foraging grounds near the nesting site that they used intensively (salt marshes, extensive grassland and wetland), resulting in small home ranges (Grajetzky and Nehls 2017). The tagged males in our study came from a big colony and showed partly overlapping home ranges. Moving within large home ranges might help to switch immediately to another already known foraging ground in case food shortage would occur at one site. Further studies about habitat structure and food availability are needed to explain the differences in home ranges at different sites.

\section{Social interactions}

Semi-colonial nesting is considered to be safer in terms of predation risk (Arroyo et al. 2001; Mougeot and Arroyo 2009; Wiacek 2008) because intruders are more easily detected and attacked by the recruitment of numerous birds. When tagging the birds, we found that two females did not take care of a nest, being either non-breeders or having suffered an early nest loss. Nevertheless, the fact that they attacked the decoy when being tagged shows that they took an active part in defending the colony's welfare, thus decreasing individual costs of nest defence (Arroyo et al. 2001). Communal roosting could help with predator detection at the roost site and thus provide benefits to all members of the group (Wiacek 2010). We observed most communal roosting of tagged males in the pre-breeding period and of females during post-breeding.

We found indication for alloparental care. After nest loss, the scarce movements within a nearby colony suggest that one female took care of fledglings in another nest. This behaviour has rarely been described in the literature, possibly because it is difficult to detect (Greenwell and Bell 1955, Arroyo and Garcia 2002, Janowski et al. 2014; see also alloparental care in Ospreys, Pandion haliaetus, Siverio et al. 2011). The data do not show alloparental care in males, but do not exclude it either, in particular giving the consistently extended flights of males within the breeding site.
Other kinds of social interactions were observed during breeding: we found one female being actively in contact by daily flights to another, nearby colony after nest loss (Fig. 5). Interestingly, other species show similar behaviour during breeding: inspecting conspecifics' breeding site (with same day returns to the nesting site) were also recorded for females of the territorial Lesser Spotted Eagle (Aquila pomarina), as well as for Osprey (Pandion haliaetus) in North Germany (Meyburg et al. 2007, 2013).

\section{Post-breeding}

Some studies (Schlaich et al. 2017, Krupiński et al. 2021) distinguished yearly movement patterns as pre-breeding, breeding, wintering and migration periods, suggesting that post-breeding movements-before migration onset-were not obvious. The time spent from arrival until migration onset varies considerably: in Poland 92 days on average (Krupiński et al. 2021), in the Netherlands about 100 days for females and up to 120 days for males (Schlaich et al. 2017), in North-West Germany 77-115 days (Greiwe 2020). Harriers in our study area spent 116-141 days in total from arrival at the breeding site to migration onset (Table 1), including pre-migratory movements to other sites up to $270 \mathrm{~km}$ away. Apparently, post-breeding and pronounced pre-migratory movements are only possible for individuals that stay in Europe for relatively long periods. This may correlate with strong latitudinal variation in arrival and laying date (Arroyo et al. 2004).

Some studies (Arroyo et al. 2002a; Trierweiler et al. 2007; Limiñana et al. 2008; Strandberg et al. 2008) report about post-breeding pre-migratory movements of longer periods (up to 68 days) for the Circus species. They explained these movements as visiting of neighbouring Montagu's Harrier breeding areas and "prospecting" for future breeding sites, as well as to fuel up before migration start. Trierweiler et al. (2007) suggest that pre-migratory visits to other areas might be visits to their natal site, similar to what has also been observed in Osprey (Hake et al. 2001). In our study, most females (six out of ten) performed pre-migratory visits to other breeding colonies, with site fidelity over the years, and independently of breeding success or failure. All but two returned to the breeding site before migration start; such a behaviour was also reported for one female of Marsh Harrier (Strandberg et al. 2008). Other individuals stayed most of the time at the breeding ground before migration onset. One female (4490) first visited colonies in 'La Serena', then explored different sites and finally fuelled up at an elevated plain before migration onset (purple in Fig. 1a).

We concur with the hypothesis by Strandberg et al. (2008), who judged pre-migratory movements not to be 
related to unsuccessful breeding attempts but estimated these movements as an individual characteristic. Though food availability was not studied, we found no evidence that staging areas used during pre-migration were characterised by better food availability as described by Limiñana et al. (2008). Areas sizes covered at 'same colony' (breeding site) or 'other colony' during post-breeding did not differ statistically (Fig. 3). Limiñana et al. (2012b) suggest that failed breeders and non-breeders may start migration earlier than successful females, who may need more time to refuel after a demanding breeding period. Surprisingly, in our study, successful females started migration significantly earlier than failed females (Table 1, Fig. 6), in contrast to that view. This suggests that food provision is not the limiting factor for migration start, at least not in 'La Serena'. Strandberg et al. (2008) hypothesise that a shortened premigratory period could compensate for a delayed breeding season, to ensure timely departure. Our data do not show such an effect. For example, female 4400-17 (early arrival) stayed in Spain for 116 days, female 4489-18 (late arrival) for 118 days (Table 1, Fig. 6).

The post-breeding period for males may coincide with the period the fledglings have left the breeding area (Arroyo et al. 2002b) and the adults primarily fuel up for migration start. For the three tagged males who all stayed at the breeding site, we cannot distinguish a pronounced post-breeding period and their number is too small for a meaningful statement.

\section{Site fidelity}

Our data confirm high site fidelity for the breeding ground. Assuming high natal dispersion for young harriers (Arroyo et al. 2004; Limiñana et al. 2012a; Bourrioux et al. 2017; Chadœuf et al. 2017; Janowski et al. 2018), and site fidelity for established breeding pairs (Arroyo et al. 2004, Trierweiler 2010, Limiñana et al. 2012a, Janowski 2015, Janowski et al. 2018), we hypothesise that a considerable part of young breeding pairs in our study area might have originated from other colonies in Extremadura or neighbouring regions.

All tagged females showed site fidelity to their postbreeding site. It is plausible, therefore, that these localities might be their natal site, as suggested previously (Trierweiler 2010). This has also been observed in the Osprey Pandion haliaetus (Hake et al. 2001). If true, that would indicate-for our sample over returning females-that $50 \%$ (three out of six) had dispersed to an area different from their natal site. This would support the wing-tagging studies of Bourrioux et al. (2017) who found that $50 \%$ of resightings were $>80 \mathrm{~km}$ from the birth's nest in France. Natal dispersal events of female Montagu's Harrier, and to a lesser extent of males, occurred among the three main breeding areas in France (Bourrioux et al. 2017).
One could hypothesise that fledglings disperse to remote colonies by following adult individuals along their postbreeding flights. Possibly, they make settling decisions for the next year, i.e. for their first breeding year. Given the site fidelity observed here, this interchange would ensure sufficient gene flow between the populations.

\section{Conclusions}

Montagu's Harrier as a semi-colonial raptor represents a very complex form of social structure. Breeding pairs and non-breeders live close together within a colony. Social interactions between nearby colonies exist, especially when breeding activities have terminated (e.g. communal roosting, mutual visits). These interactions between individuals and remote colonies were consistent across seasons, confirming high site fidelity. More and longer lasting studies (including genetic analyses as done by Janowski et al. 2018 and Ribout et al. 2019) should be carried out to get more information about communication between individuals and gene flow between the colonies. In future, technical improvements to reduce size and weight of devices should allow to include juveniles into tracking studies and get further insights into behavioural patterns of this semi-colonial raptor.

Supplementary Information The online version contains supplementary material available at https://doi.org/10.1007/s10336-021-019149. In addition, interactive material is available at https://neuro.uni.kn/ harrier.

Acknowledgements Many volunteers helped with field work locating and monitoring nest sites over the years. Special thanks are due to Manuel Calderón, president of ANSER (Asociación de Amigos de la Naturaleza de la Serena) and president of GEA (Grupo Extremeño de Aguiluchos), who was responsible for funding and implementing the annual conservation campaigns, and for applying for trapping and tagging permits. The tracking studies were facilitated by GPS-GSM loggers made by the scientific workshops of the University of Konstanz, Germany, and Ornitela loggers provided by GEA and funded by the Dirección General de Sostenibilidad of the Extremadura government. Special thanks to those persons who were involved in trapping and tagging the birds: José María Traverso, José María Abad, Domingo Rivera, Antonio Pinilla, Alfonso Godino. Thanks for handling, analysing and visualizing the data on Movebank to Martin Wikelski and Bernd Vorneweg from the Max Planck Institute for Animal Behavior, Germany as well as to Mindaugas Dagys for providing Ornitela data to our study. Wolfgang Fiedler helped in many ways along the study. Beatriz Arroyo contributed helpful comments on the first draft of the manuscript. Helpful comments of Almut Schlaich and an anonymous reviewer improved the manuscript in many ways. This work complies with the current environmental laws in Spain. All necessary permissions to catch Montagu's Harrier and deploy transmitters were provided by the environmental department of Extremadura government. We acknowledge funding from GEA and the Extremadura regional government, as well as Deutsche Forschungsgemeinschaft (DFG, German Research Foundation) under Germany's Excellence Strategy - EXC $2117-422037984$. 
Funding Open Access funding enabled and organized by Projekt DEAL.

Availability of data and materials The datasets analysed during the current study are available from the corresponding author on reasonable request.

\section{Declarations}

Conflict of interest The authors declare that they have no conflict of interest.

Ethics approval All applicable institutional and/or national guidelines for the care and use of animals were followed.

Open Access This article is licensed under a Creative Commons Attribution 4.0 International License, which permits use, sharing, adaptation, distribution and reproduction in any medium or format, as long as you give appropriate credit to the original author(s) and the source, provide a link to the Creative Commons licence, and indicate if changes were made. The images or other third party material in this article are included in the article's Creative Commons licence, unless indicated otherwise in a credit line to the material. If material is not included in the article's Creative Commons licence and your intended use is not permitted by statutory regulation or exceeds the permitted use, you will need to obtain permission directly from the copyright holder. To view a copy of this licence, visit http://creativecommons.org/licenses/by/4.0/.

\section{References}

Amar A, Arroyo BE, Bretagnolle V (2000) Post-fledging dependency and dispersal in hacked and wild Montagu's Harriers Circus pygargus. Ibis 142:21-28

Arroyo B (1995) Breeding ecology and nest dispersion of Montagu's Harrier Circus pygargus in Central Spain. $\mathrm{PhD}$ thesis, University of Oxford

Arroyo BE, Bretagnolle V (2000) Evaluating the long-term effectiveness of conservation practices in Montagu's Harrier Circus pygargus. In: Chancellor RD, Meyburg B-U (eds) Raptors at risk. Pica Press, Bodmin, Cornwall, pp 403-408

Arroyo B, Garcia JT (2002) Alloparental care and kleptoparasitism in the semicolonial Montagu's Harrier Circus pygargus. Ibis 144:676-679

Arroyo B, Mougeot F, Bretagnolle V (2001) Colonial breeding and nest defence in Montagu's Harrier (Circus pygargus). Behav Ecol Sociobiol 50(2):109-115

Arroyo B, Garcia JT, Bretagnolle V (2002a) Conservation of Montagu's Harrier Circus pygargus in agricultural areas. Anim Cons 5:283-290

Arroyo BE, De Cornulier Th, Bretagnolle V (2002b) Parental investment and parent-offspring conflicts during the post-fledging period in Montagu's Harriers. Anim Behav 63:235-244

Arroyo B, Garcia JT, Bretagnolle V (2004) Circus pygargus Montagu's Harrier. BWP Update 6(1 and 2):39-53

Arroyo B, Molina B, Del Moral JC (2019) El Aguilucho cenizo y el Aguilucho pálido en España. Población reproductora en 2017 y método de censo. SEO/BirdLife, Madrid

Benhamou S, Cornelis D (2010) Incorporating movement behavior and barriers to improve biological relevance of kernel home range space use estimates. J Wildl Manag 74:1353-1360

Berger-Geiger B, Galizia CG (2019) Kameraüberwachung von Nestern der Wiesenweihe Circus pygargus in der spanischen Extremadura:
Neue Erkenntnisse zu Prädation und Beteiligung von Männchen am Nistgeschehen. Vogelwarte 57(3):173-182

Berger-Geiger B, Galizia CG, Arroyo B (2019) Montagu's Harrier breeding parameters in relation to weather, colony size and nest protection schemes: a long-term study in Extremadura, Spain. J Ornithol 160:429-441

Berthold P (2001) Bird migration: a general survey. Oxford University Press, Oxford

Bourrioux JL, Printemps T, van Hecke B, Villers A, Chadoeuf J, Augiron S, Bretagnolle V, Millon A (2017) Bilan de dix ans de marquage des jeunes Busards cendrés Circus pygargus en France. Ornithos 24:305-322

Bouten W, Baaij E, Shamoun-Baranes J, Camphuysen KJ (2013) A flexible GPS tracking system for studying bird behaviour at multiple scales. J Ornithol 154:571-580

Bridge ES, Thorup K, Bowlin MS, Chilson PB, Diehl RH, Fléron RW, Hartl P, Kays R, Kelly JF, Robinson WD, Wikelski M (2011) Technology on the move: recent and forthcoming innovations for tracking migratory birds. Bioscience 61:689-698

Caccamise DF, Robert SH (1985) An aerodynamic basis for selecting transmitter loads in birds. Wilson Bull 97:306-318

Calenge C (2006) The package adehabitat for the R software: a tool for the analysis of space and habitat use by animals. Ecol Model 197:516-519

Calenge C (2019) Home range estimation in R: the adehabitatHR package. https://www.rdocumentation.org/packages/adehabitatHR/ versions/0.4.16. Accessed Feb 2021

Chadœuf J, Millon A, Bourrioux JL, Printemps T, van Hecke B, Lecoustre V, Bretagnolle V (2017) Modelling unbiased dispersal kernels over continuous space by accounting for spatial heterogeneity in marking and observation efforts. Methods in Ecol Evol 9:331-339

Choi C-Y, Takekawa JY, Yue X, Ying L, Wikelski M, Heine G, Prosser DJ, Newman SH, Edwards J, Guo F, Xiao X (2016) Tracking domestic ducks: a novel approach for documenting poultry market chains in the context of avian influenza transmission. J Integr Agric 15:1584-1594

Clarke R (1996) Montagu's Harrier. Arlequin Press, Chelmsford, Essex, U.K.

Fiedler W (2009) New technologies for monitoring bird migration and behaviour. Ring Migr 24:175-179

Grajetzky B, Nehls G (2017) Telemetric monitoring of Montagu's Harrier in Schleswig-Holstein. In: Hötker $\mathrm{H}$ et al (eds) Birds of prey and wind farms. Springer, Cham, pp 97-148

Greenwell CJ, Bell N (1955) Strange behaviour of Montagu's Harriers. Brit Birds 48:277-279

Greiwe TU (2020) Raumnutzung der Wiesenweihen in einer intensiv genutzten Agrarlandschaft: Eine Analyse hochauflösender Satellitentracking-Daten. Westfälische Wilhelms-Universität Münster, Masterarbeit

Guixé D, Arroyo B (2011) Appropriateness of special protection areas for wide ranging species: the importance of scale and protecting foraging, not just nesting habitats. Anim Cons 14:391-399

Hake M, Kjellén N, Alerstam T (2001) Satellite tracking of Swedish ospreys Pandion haliaetus: autumn migration routes and orientation. J Avian Biol 32:47-56

Janowski S (2015) Untersuchung zur Brutbiologie und Populationsgenetik der Wiesenweihe (Circus pygargus) mittels MikrosatellitenAnalyse. Dissertation. University of Heidelberg

Janowski S, Grohme MA, Frohme M, Wink M (2014) Development of new microsatellite (STR) markers for Montagu's Harrier (Circus pygargus) via 454 shot-gun pyrosequencing. Open Ornithol J 7:11-18

Janowski S, Puerckhauer C, Krüger R, Tietze T, Wink M (2018) Recruitment rates, natal and breeding dispersal of Montagu's Harriers by means of microsatellite analysis. Open Ornithol J 11:39-55 
Kays R, Crofoot MC, Jetz W, Wikelski M (2015) Terrestrial animal tracking as an eye on life and planet. Science 348(aaa2478):1-9

Kenward RE (2001) A manual for wildlife radio tagging. Academic Press, London

Kitowski I (2002) Behaviour of Montagu's Harrier juveniles during the post-fledging dependency period in southeast Poland. Berkut 12:201-207

Klaassen RHG, Hake M, Strandberg R, Koks B, Trierweiler C, Exo KM, Bairlein F, Alerstam T (2014) When and where does mortality occur in migratory birds? Direct evidence from long- term satellite tracking of raptors. J Anim Ecol 83:76-184

Klaassen RHG, Schlaich AE, Both C, Bouten W, Koks B (2019) Individual variation in home range size reflects different space use strategies in a central place foraging raptor bird. In: Schlaich AE (2019) Migrants in double jeopardy. PhD thesis submitted to Rijksuniversiteit Groningen, p 114-133

Krupiński D, Kotowska D, Recio MR, Żmihorski M, Obłoza P, Mirski P (2021) Ranging behaviour and habitat use in Montagu's Harrier Circus pygargus in extensive farmland of Eastern Poland. J Ornithol 162:25-337. https://doi.org/10.1007/s10336-020-01837-x

Limiñana R, Soutullo A, Lopez-Lopez P, Urios V (2008) Pre-migratory movements of adult Montagu's Harriers Circus pygargus. Ardea 96:81-90

Limiñana R, Garcia JT, Gonzalez JM, Guerrero A, Lavedan J, Moreno JD, Arroyo B (2012a) Philopatry and natal dispersal of Montagu's Harriers (Circus pygargus) breeding in Spain: a review of existing data. Eur J Wildl Res 58:549-555

Limiñana R, Soutullo A, Urios V, Reig-Ferrer A (2012b) Migration and wintering areas of adult Montagu's Harriers (Circus pygargus) breeding in Spain. J Ornithol 153:85-93

Martinez-Miranzo B, Banda E, Gardiazébal A, Ferreiro E, Aguirre JI (2016) Differential spatial use and spatial fidelity by breeders in Bonelli's Eagle (Aquila fasciata). J Ornithol 157:971-979

Meyburg B-U, Meyburg C (2013) Telemetrie in der Greifvogelforschung. Greifvögel Und Falknerei 2013:26-60

Meyburg B-U, Meyburg C, Franck-Neumann F (2007) Why do female lesser spotted eagles (Aquila pomarina) visit strange nests remote from their own? J Ornithol 148:157-166

Mougeot F and Arroyo B (2009) Ecología comportamental del Aguilucho Cenizo: colonialismo y comportamiento social. In: Alarcos et al. (eds.) Conservación y situación poblacional de los Aguiluchos en Eurasia. Ed. Dirección General del Medio Natural. Consejería de Industria, Energía y Medio Ambiente. Junta de Extremadura. Badajoz, p 61-70

Ribout C, Villers A, Ruault S, Bretagnolle V, Picard D, Monceau K, Gauffre B (2019) Fine-scale genetic structure in a high dispersal capacity raptor, the Montagu's Harrier (Circus pygargus), revealed by a set of novel microsatellite loci. Genetica 147:69-78

Salamolard M (1997) Utilisation de l'espace par le Busard Cendré Circus pygargus, superficie et distribucion des zones de chasse. Alauda 65:307-320

Schlaich AE, Klaassen RHG, Bouten W, Both C, Koks B (2015) Testing a novel agri-environment scheme based on the ecology of the target species, Montagu's Harrier Circus pygargus. Ibis 157:713-721

Schlaich AE, Bouten W, Bretagnolle V, Heldbjerg H, Klaassen RHG, Sørensen IH, Villers A, Both C (2017) A circannual perspective on daily and total flight distances in a long-distance migratory raptor, the Montagu's Harrier, Circus pygargus. Biol Lett 13:20170073
Siverio M, Siverio F, Rodriguez B (2011) Observations on alloparental care of fledglings in Osprey Pandion haliaetus. VIERAEA 39:105-110

Strandberg R, Klaassen RHG, Hake M, Olofsson P, Thorup K, Alerstam T (2008) Complex timing of Marsh Harrier Circus aeruginosus migration due to pre- and post-migratory movements. Ardea 96:159-171

Terraube J, Arroyo B (2011) Factors influencing diet variation in a generalist predator across its range distribution. Biodivers Conserv 20:2111-2131

Trierweiler C, Koks B, Drent RH, Exo KM, Komdeur J, Dijkstra C, Bairlein F (2007) Satellite tracking of two Montagu's Harriers (Circus pygargus): dual pathways during autumn migration. J Ornithol 148:513-516

Trierweiler C, Drent RH, Komdeur J, Koks BJ (2010) Home range size and habitat selection of the endangered Montagu's Harrier Circus pygargus in NW Europe: implications for conservation. In: Trierweiler $\mathrm{C}$ Travels to feed and food to breed. The annual cycle of a migratory raptor, Montagu's Harrier, in a modern world. Dissertation. Rijksuniversiteit Groningen, p 47-67

Trierweiler C, Klaassen RHG, Drent RH, Exo K-M, Komdeur J, Bairlein F, Koks BJ (2014) Migratory connectivity and populationspecific migration routes in a long-distance migratory bird. Proc R Soc B 281:20132897

Vansteelant WMG, Bouten W, Klaassen RHG, Koks BJ, Schlaich AE, van Diermen J, van Loon EE, Shamoun-Baranes J (2015) Regional and seasonal flight speeds of soaring migrants and the role of weather conditions at hourly and daily scales. J Avian Biol 46:25-39

Vardi Y, Zhang CH (2000) The multivariate L1-median and associated data depth. PNAS 97:1423-1426

Waskom M, Gelbart M, Botvinnik O, Brunner T (2020) mwaskom/ seaborn: v0.11.1 (December 2020). Zenodo. https://doi.org/10. 5281/zenodo.4379347

Wiacek J (2008) Benefits and costs of semi-colonial breeding in the Montagu's Harrier Circus pygargus. Belgian J Zool 138:36-40

Wiacek J (2010) Mixed roosts in the Montagu's Harrier Circus pygargus during courtship. Biologia 65:338-343

Wikelski M, Kays R (2010) Movebank: archive, analysis and sharing of animal movement data. https://www.movebank.org/. Hosted by the Max Planck Institute for Animal Behavior. Accessed Feb 2021

Wikelski M, Kays RW, Kasdin J, Thorup K, Smith JA, Cochran WW, Swenson GW Jr (2007) Going wild-what a global small-animal tracking system could do for experimental biologists. J Exp Biol 210:181-186

Proof Male 191644 returned to the same site in 2021, the year following the data reported in this paper, and stayed in the same area after the nesting season, confirming the results in this paper. The other two males' tags stopped working, or the animals died. Noteadded in proof: male 191644 returned to the same site in 2021, the yearfollowing the data reported in this paper, and stayed in the same area afterthe nesting season, confirming the results in this paper. The other two males' tagsstopped working, or the animals died.

Publisher's Note Springer Nature remains neutral with regard to jurisdictional claims in published maps and institutional affiliations. 